2016-03-21

\title{
Quantitative estimates of sinking sea ice particulate organic carbon based on the biomarker IP25
}

\section{Brown, Thomas}

http://hdl.handle.net/10026.1/4416

\subsection{4/meps11668 \\ Marine Ecology Progress Series \\ Inter-Research Science Center}

All content in PEARL is protected by copyright law. Author manuscripts are made available in accordance with publisher policies. Please cite only the published version using the details provided on the item record or document. In the absence of an open licence (e.g. Creative Commons), permissions for further reuse of content should be sought from the publisher or author. 
Disclaimer: This is a pre-publication version. Readers are recommended to consult the full published version for accuracy and citation.

1

2

3

4

5

6

7

8

9

10

11

12

13

14

15

16

17

18

19

20

21

Quantitative estimates of sinking sea ice particulate organic carbon based on the biomarker IP 25

\section{T. A. Brown ${ }^{1, *}$, S. T. Belt ${ }^{1}$, M. Gosselin ${ }^{3}$, M. Levasseur ${ }^{4}$, M. Poulin ${ }^{5}$, C. J. Mundy ${ }^{2}$}

${ }^{1}$ School of Geography, Earth and Environmental Sciences, University of Plymouth,

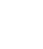

${ }^{2}$ Centre for Earth Observation Science (CEOS), University of Manitoba, Winnipeg,

\section{Manitoba R3T 2N2, Canada}

${ }^{3}$ Institut des sciences de la mer de Rimouski, Université du Québec à Rimouski, Rimouski,

${ }^{4}$ Département de biologie, Québec-Océan, Université Laval, Québec, Québec G1V 0A6,

${ }^{5}$ Research and Collections Division, Canadian Museum of Nature, PO Box 3443 Station D, Ottawa, Ontario K1P 6P4, Canada

7 * Corresponding author: Thomas.brown@plymouth.ac.uk

9 Running head - Quantifying sea ice organic carbon 
Disclaimer: This is a pre-publication version. Readers are recommended to consult the full published version for accuracy and citation.

\section{ABSTRACT}

Sea ice derived particulate organic carbon (iPOC) represents an important

contribution of carbon to Arctic ecosystems, yet our ability to obtain realistic quantitative estimates of iPOC outside of the sea ice matrix is currently somewhat limited. To address this challenge, we applied a novel approach to quantifying iPOC within the water column under melting sea ice by first measuring the proportion of the sea ice diatom biomarker $\mathrm{IP}_{25}$ within iPOC in bottom ice samples obtained from Resolute Passage in spring 2012. We then compared this value with corresponding values obtained from a time series of water samples. Together, these reflected a period of ice melt and rapid release of iPOC, indicated by changing ice temperature and thickness, in addition to changes in the stable carbon isotope composition, and concentration of iPOC, $\mathrm{IP}_{25}$ and chlorophyll $a$ within bottom ice. Estimates of iPOC in seawater were highest $\left(0.15-0.22 \mathrm{mg} \mathrm{l}^{-1}\right)$ in the upper $2 \mathrm{~m}$, coincident with the reduction of iPOC in sea ice near the beginning of sampling, with iPOC accounting for an estimated $84-125 \%$ of total POC (tPOC). Collectively, this biomarker approach yielded realistic estimates of \%iPOC, both numerically, and in the context of melting sea ice following a spring bloom in the Canadian Arctic. We also describe some assumptions of this approach and consider the impacts of possible caveats on quantitative estimates of iPOC derived from it.

KEY WORDS: $\mathrm{IP}_{25}$, diatom, spring sea ice bloom, POC, carbon budget, Resolute Passage, quantitative, 
Disclaimer: This is a pre-publication version. Readers are recommended to consult the full published version for accuracy and citation.

\section{INTRODUCTION}

Sea ice associated primary production can represent an important contribution of carbon to Arctic pelagic and benthic marine ecosystems (Arrigo et al. 2010). Optimal conditions for sea ice associated primary production occur in spring when nutrient rich water coupled with sufficient solar radiation provide the stimulus for phototrophic growth (Arrigo et al. 2010). This part of the productive period, commonly referred to as the spring bloom, is terminated when sea ice melts, releasing accumulated organic carbon biomass into the underlying ocean (Michel et al. 1996, 2002, Fortier et al. 2002, Leventer 2003, Dieckmann \& Hellmer 2010, Arrigo 2014). With estimated sea ice carbon production ranging from $0.2-23$ $\mathrm{g} \mathrm{C} \mathrm{m}^{-2} \mathrm{y}^{-1}$ (Arrigo et al. 2010), sea ice can provide an important contribution to the carbon available to pelagic heterotrophs (Søreide et al. 2010, Forest et al. 2011a, Brown \& Belt 2012a, Wang et al. 2014) in a relatively short time. Indeed, it is known that some organisms time their grazing activities to coincide with spring sea ice blooms (Renaud et al. 2007, Søreide et al. 2010, Leu et al. 2011), thus enabling effective uptake of sea ice carbon into the pelagic and benthic ecosystem. In some cases, sea ice carbon concentration exceeds the grazing potential of pelagic organisms (Forest et al. 2011b), such that sedimentation occurs, making sea ice carbon also accessible to benthic ecosystems (Arrigo 2014). However, challenges associated with distinguishing sea ice carbon from that derived from marine and terrestrial sources, complicates attempts to quantify the former in the pelagic environment. Despite these challenges, however, some approaches have been used for distinguishing sea ice carbon in samples that also contain carbon derived from additional sources. For instance, determination of the stable carbon isotope composition $\left(\delta^{13} \mathrm{C}\right)$ of particulate organic carbon (POC) can potentially provide information on the relative contributions of different organic carbon sources since sea ice particulate organic carbon (iPOC) is usually more enriched in ${ }^{13} \mathrm{C}$ (e.g. $\delta^{13} \mathrm{C}-11 \%$; Pineault et al. 2013) compared to pelagic particulate organic carbon 
72 (pPOC) (e.g. $\delta^{13} \mathrm{C}-27 \%$; Pineault et al. 2013). However, end-member values are not fixed,

in practice, and temporal changes in the isotopic composition of dissolved inorganic carbon

(Munro et al. 2010, Pineault et al. 2013) can complicate the interpretation of isotopic data, especially within samples of sea ice. As such, the isotopic signature $\left(\delta^{13} \mathrm{C}\right)$ of iPOC is strongly influenced by sea ice DIC and, in some cases, overlaps with values obtained from pPOC. For example, Tremblay et al. (2006) observed overlap in the isotopic composition of iPOC $\left(\delta^{13} \mathrm{C}-9\right.$ to $\left.-26 \%\right)$ with pPOC $\left(\delta^{13} \mathrm{C}-20\right.$ to $-27 \%$ ) in the North Water Polynya in spring 1998, noting that the greatest overlap occurred early in sampling from relatively thin ice $(<80 \mathrm{~cm})$. Similarly, Forest et al. (2011a) reported the isotopic composition of both sea ice and pelagic particulate organic matter in the Amundsen Gulf during spring 2008, where mean values ranged -24 to $-31 \%$ and overlapped most closely at the beginning of sampling where ice and pelagic samples were almost indistinguishable, isotopically, from each other. The determination of the stable isotopic composition of specific lipid biomarkers has also been used to provide information on the source of individual components of iPOC (Budge et al. 2008). Fatty acids are routinely measured for this purpose since they are a major component of algal lipids and contribute substantially to carbon biomass in both iPOC and pPOC. Budge et al. (2008) determined the isotopic composition of certain fatty acids in sea ice algae from Barrow, Alaska, in 2002, reporting $\delta^{13} \mathrm{C}$ values of $-24.0 \pm 2.4 \%$ and $-18.3 \pm$ $2.0 \%$ for $16: 4 n-1$ and $20: 5 n-3$, respectively. In contrast, the same fatty acids in the cosampled phytoplankton were lighter, with $\delta^{13} \mathrm{C}-30.7 \pm 0.8 \%$ and $-26.9 \pm 0.7 \%$. While the reported end-members were clearly different in this study, Budge et al. (2008) noted that there may be further isotopic variations in pelagic iPOC at other times of the year, thus making it more difficult to establish reliable end-member values. In addition, Budge et al. (2008) noted that some 20:5n-3 may be derived from non-diatom sources (Volkman et al. 1998) and these would likely influence the isotopic composition of this biomarker. 
Disclaimer: This is a pre-publication version. Readers are recommended to consult the full published version for accuracy and citation.

The analysis of phototrophic microorganism accessory pigments can provide

98

information on the biological composition of POC (Morata \& Renaud 2008). For example, fucoxanthin (from diatoms) was found to be particularly abundant in Barents Sea surface sediments collected in spring from 2003 to 2005 (Morata \& Renaud 2008). Further, chlorophyll $b$, a marker of green algae, was found in Arctic-influenced sediments, while 19'hex-fucoxanthin, a marker of prymnesiophytes, was found in Atlantic-influenced sediments. Measurement of chlorophyll $a(\mathrm{chl} a)$ and phaeopigments also provided information on the freshness of sinking organic carbon, leading to the conclusion that fresh diatom material was being sedimented in spring due to close pelagic-benthic coupling. However, since sea ice and pelagic microorganisms can produce the same pigments, analysis of these alone does not provide a means of unambiguously distinguishing between individual POC sources.

$$
\text { Limitations of individual methods can, to some extent, be overcome by employing }
$$
multiple approaches. For example, Michel et al. (1996) combined pigment analysis with physical and biological measurements made in Resolute Passage (central Canadian Arctic) to estimate that $>65 \%$ of iPOC released from melting sea ice remained suspended in the water and was subsequently grazed upon by heterotrophs. Similarly, Forest et al. (2011b) combined pigment and carbon stable isotope analysis with physical and biological measurements in the southeast Beaufort Sea, to estimate that ice algae contributed $\sim 6 \%$ to gross primary production in spring-summer 2008. What remains clear, however, is that the development of further complementary approaches for estimating the contribution of sea ice carbon after its release from sea ice would enhance our understanding of its importance to pelagic and benthic ecosystems.

To be considered complementary, any new approach should address at least some of the limitations of existing methods and, ideally, be based on the measurement of a physical, biological or chemical parameter that is unique to iPOC and is quantifiable in samples of sea 
Disclaimer: This is a pre-publication version. Readers are recommended to consult the full published version for accuracy and citation.

ice, seawater and sediment from any part of the Arctic. Furthermore, in order for such a measure to be effective, its native proxy signature must be retained following release from melting sea ice into the water column (and beyond). For biological- or chemical-based proxies, this means retention of the source composition of the proxy per unit carbon being retained within, for example, seawater or sediment. Finally, the identification and quantification of such a proxy needs to be unambiguous and reliable. In recent years, a novel lipid produced by certain Arctic sea ice-dwelling diatoms has been identified that possesses these attributes and analytical requirements.

$\mathrm{IP}_{25}$ ('Ice-Proxy with 25 carbon atoms') is a highly branched isoprenoid (HBI) lipid biomarker made by certain Arctic sea ice diatoms (Belt et al. 2007, Brown et al. 2014c) during the spring bloom (Brown et al. 2011, Belt et al. 2013b) and $\mathrm{IP}_{25}$ concentrations in sea ice correlate well with other major components of iPOC, including chl $a$ and fatty acids (Brown et al. 2011, Belt et al. 2013b). In addition, $\mathrm{IP}_{25}$ has an isotopic signature $\left(\delta^{13} \mathrm{C}-19\right.$ to $-22 \%$ ) consistent with biosynthesis in sea ice (Belt et al. 2008), even when detected in sediments. In contrast, $\mathrm{IP}_{25}$ has not been identified in Arctic phytoplankton so it appears to be only produced by sea ice diatoms. However, although $\mathrm{IP}_{25}$ is only made by a relatively small number of diatom species, these are, nevertheless, pan-Arctic in distribution (Brown et al. 2014c). Consistent with this, $\mathrm{IP}_{25}$ has been identified in seawater containing sinking iPOC (Brown 2011), sediments (Belt \& Müller 2013) and animals (Brown \& Belt 2012b, Brown et al. 2012, Brown et al. 2014a) across the Arctic.

Laboratory experiments have demonstrated that $\mathrm{IP}_{25}$ is substantially more stable to oxidation than other major components of iPOC, including chl $a$ and fatty acids (Rontani et al. 2011). Additionally, the identification of $\mathrm{IP}_{25}$ within marine animal tissues spanning various trophic levels (Brown et al. 2014d), and in ancient marine sediments as old as $3.9 \mathrm{Ma}$ old (Knies et al. 2014), confirms that $\mathrm{IP}_{25}$ is particularly resilient to alteration following 
Disclaimer: This is a pre-publication version. Readers are recommended to consult the full published version for accuracy and citation.

147 biosynthesis. Finally, rigorous analytical protocols for the identification and quantification of

$148 \mathrm{IP}_{25}$ in sea ice, seawater and sediments have been developed (Brown et al. 2011, Belt et al.

149 2012, 2013a). Combined, these attributes suggest that the analysis of $\mathrm{IP}_{25}$ represents a

150 potentially ideal candidate for the quantification of iPOC in the Arctic.

151 For the analysis of $\mathrm{IP}_{25}$ to provide quantitative estimates of iPOC in seawater (rather

152 than simply a qualitative indicator of presence/absence), the proportion of $\mathrm{IP}_{25}$ to total iPOC

153 in sea ice needs to be known. This can be expressed as the ratio $\mathrm{iPOC}_{\mathrm{i}} / \mathrm{IP}_{25 \mathrm{i}}$ where $\mathrm{iPOC}_{\mathrm{i}}$ and

$154 \mathrm{IP}_{25 \mathrm{i}}$ correspond to the measured concentrations of ice-derived POC and $\mathrm{IP}_{25}$, respectively.

155 Quantification of iPOC in seawater (i.e. $\mathrm{iPOC}_{\mathrm{w}}$ ) can then be determined by combining $\mathrm{IP}_{25}$

156 concentrations measured in seawater with $\mathrm{iPOC}_{\mathrm{i}} / \mathrm{IP}_{25 \mathrm{i}}$ on the assumption that there is no

157 significant change to this ratio. In addition, since both $\mathrm{IP}_{25}$ and $\mathrm{iPOC}$ are transferred to the

158 water column during ice melt, and become incorporated into total particulate organic carbon

159 in the water column $\left(\mathrm{tPOC}_{\mathrm{w}}\right)$, there should be an overall dilution of $\mathrm{IP}_{25}$ and a subsequent

160 increase in $\mathrm{POC} / \mathrm{IP}_{25}$ compared to that found in ice. As a result, it is hypothesised that

161 comparison of $\mathrm{PPOC}_{\mathrm{w}}$ (calculated) with $\mathrm{APOC}_{\mathrm{w}}$ (measured) in seawater samples should

162 provide an estimate of the proportion of iPOC in seawater POC (i.e. \%iPOC ${ }_{w}$ ).

The purpose of this study, therefore, was to test this hypothesis by measuring $\operatorname{IP}_{25}$ and

164 POC in sea ice and seawater samples obtained during springtime ice melt to see if these

165 provided realistic estimates of $\mathrm{PPOC}_{\mathrm{w}}$ and $\% \mathrm{iPOC}_{\mathrm{w}}$ following a spring bloom. To achieve

166 this, a time series of bottom sea ice cores and seawater samples was collected from Resolute

167 Passage, Canada and analysed for $\mathrm{IP}_{25}$, POC and other physical and biochemical parameters 168 to provide some necessary context. 
Disclaimer: This is a pre-publication version. Readers are recommended to consult the full published version for accuracy and citation.

Sampling was conducted at a landfast ice station $\left(74^{\circ} 43.6^{\prime} \mathrm{N}, 95^{\circ} 33.5^{\prime} \mathrm{W}\right)$ located

172

173

174

175

176

177

178

179

180

181

182

183

184

185

between Griffith Island and Sheringham Point (Cornwallis Island) in Resolute Passage

(central Canadian Arctic archipelago) from 22 May to 23 June 2012, within the framework of the Arctic-ICE project (Mundy et al. 2014). Vertical profiles of temperature and salinity were measured from $2-80 \mathrm{~m}(\max$ water depth $=90 \mathrm{~m})$ with a Sea-Bird SBE 19plus V2 conductivity-temperature-depth (CTD) probe every $1-2$ days throughout the study period. Sectioned sea ice core samples (bottom $0-3 \mathrm{~cm}$ ) were collected every $3-4$ days from an area of low snow cover $(<10 \mathrm{~cm})$ using a $9 \mathrm{~cm}$ internal diameter core barrel (Kovacs Mark II). To compensate for biomass heterogeneity in sea ice (Gosselin et al. 1986), 2 - 3 core bottoms were pooled for each sampling day in isothermal containers. Pooled sea ice cores were then melted in $0.2 \mu \mathrm{m}$ filtered seawater ( 3 part FSW to 1 part melted ice) to minimize osmotic stress on the microbial community during melting (Garrison \& Buck 1986). A further ice core was obtained to measure the bottom ice (approximately $2.5 \mathrm{~cm}$ from the ice/water interface) temperature by drilling a $2 \mathrm{~mm}$ hole to the centre of the core and inserting a temperature probe (Testo 720 probe). Water samples were collected at the same frequency at 2, 5, 10, 25, 50 and $80 \mathrm{~m}$ under the sea ice using large (5 1) Niskin bottles to accommodate any within sample heterogeneity.

\section{Diatom cell counts and chlorophyll $a$ analysis}

At the shore laboratory, and within $24 \mathrm{~h}$ of sampling, duplicate samples of sea-ice and seawater were filtered through Whatman GF/F glass-fibre filters (nominal pore size of 0.7 $\mu \mathrm{m})$ for chl $a$ determination. Chl $a$ retained on the filters was measured using a 10-005R Turner Designs fluorometer, after $24 \mathrm{~h}$ extraction in $90 \%$ acetone for $18 \mathrm{~h}$ at $4^{\circ} \mathrm{C}$ in the dark (acidification method of Parsons et al. 1984). The flourometer was calibrated with a commercially available chl $a$ standard (Anacystis nidulans, Sigma). Selected subsamples of sea ice (bottom $0-3 \mathrm{~cm} ; 27$ May and 21 Jun) and seawater (2 m depth; 30 May and 23 Jun) 
Disclaimer: This is a pre-publication version. Readers are recommended to consult the full published version for accuracy and citation.

196 for cell identification and enumeration were preserved with acidic Lugol's solution (Parsons 197 et al. 1984) and stored in the dark at $4{ }^{\circ} \mathrm{C}$ until analysis. Diatom cells were enumerated at the 198 lowest possible taxonomic rank using inverted microscopy (Zeiss Axiovert 10) according to 199 Lund et al. (1958) where three transects were made and at least 400 cells were counted at $200400 x$.

201

202

\section{Particulate organic carbon analysis}

203

Single subsamples of sea ice and seawater were filtered onto precombusted $\left(450^{\circ} \mathrm{C}\right.$ for 204

$5 \mathrm{~h}$ ) Whatman $\mathrm{GF} / \mathrm{F}$ filters and stored frozen at $-80^{\circ} \mathrm{C}$ for analysis at the Université $\mathrm{du}$

Québec à Rimouski. Filters for the POC and stable carbon isotope determination were dried at $60^{\circ} \mathrm{C}$ for at least $24 \mathrm{~h}$, placed in a desiccator saturated with $\mathrm{HCl}$ fumes for $24 \mathrm{~h}$ to remove carbonate and pelletized. Samples were then analysed for POC concentrations and stable carbon isotope ratios using an ECS 4010 elemental analyser (Costech Analytical

Technologies Inc.) coupled to a Delta ${ }^{\text {Plus }} \mathrm{XP}$ continuous flow isotope ratio mass spectrometer

210 (Thermo Electron Corporation). Stable carbon isotope ratios are expressed as a deviation

$211\left(\delta^{13} \mathrm{C}\right.$ in \%o from the PeeDee Belemnite (PDB) standard, according to the following

212 equation: $\delta X=\left[\left(R_{\text {sample }} / R_{\text {standard }}\right)-1\right] \times 1000$, where $X$ is ${ }^{13} \mathrm{C}$ of the sample and $R$ is the

213 corresponding ratio ${ }^{13} \mathrm{C} /{ }^{12} \mathrm{C}$. Instrumental analytical error was $0.2 \%$ for $\delta^{13} \mathrm{C}$, based on

214 internal standards (limestone and sucrose) from the National Institute of Standards and

215 Technology (NIST).

\section{Lipid analysis}

At the University of Plymouth, 9-octyl-8-heptadecene $\left(10 \mu \mathrm{l} ; 2 \mu \mathrm{g} \mathrm{ml}^{-1}\right)$ and

219 nonadecanoic acid $\left(10 \mu \mathrm{l} ; 4 \mathrm{mg} \mathrm{ml}^{-1}\right)$ internal standards were added to dedicated filters for

220 quantification of $\mathrm{IP}_{25}$ and fatty acids respectively from sea ice ( $15-400 \mathrm{ml}$ filtered) and 
Disclaimer: This is a pre-publication version. Readers are recommended to consult the full published version for accuracy and citation.

221

222

223

224

225

226

227

228

229

230

231

232

233

234

235

236

237

238

239

240

241

242

243

244

245

seawater $\left(1-41\right.$ filtered). Filters were then saponified $\left(5 \% \mathrm{KOH} ; 70^{\circ} \mathrm{C} ; 30 \mathrm{~min}\right)$, after which non-saponifiable lipids (including $\left.\mathrm{IP}_{25}\right)$ were extracted with hexane $(3 \times 2 \mathrm{ml})$ and purified by open column chromatography $\left(\mathrm{SiO}_{2}\right.$; hexane; 3 column volumes). Fatty acids were obtained by adding concentrated $\mathrm{HCl}(1 \mathrm{ml})$ to the saponified solution (after extraction of nonsaponifiable lipids $)$ and re-extracted with hexane $(3 \times 2 \mathrm{ml})$. Identification of $\mathrm{IP}_{25}$ was achieved following analysis by selective ion monitoring $(\mathrm{SIM} ; \mathrm{m} / \mathrm{z} 350.3$, limit of detection $=$ $1 \mathrm{ng}^{-1}$ ) using an Agilent 7890A gas chromatograph coupled to an Agilent 5975c quadrapole EI mass spectrometer (GC-MS; HP5ms; Belt et al. 2012). Comparison of $\mathrm{IP}_{25}$ in sample extracts to the retention index obtained from a pure standard of $\mathrm{IP}_{25}$ provided unambiguous identification, while monitoring of $m / z 348.3$ enabled evaluation of the co-eluting $\mathrm{C}_{25: 2} \mathrm{HBI}$ (Belt et al. 2013a). Fatty acids were derivatised (BSTFA; $50 \mu \mathrm{l} ; 80^{\circ} \mathrm{C} ; 60 \mathrm{~min}$ ) and analysed using an HP 6890 gas chromatograph with flame ionising detector (GC-FID; HP5).

Individual fatty acids were identified by comparison of their chromatographic properties with those of authentic standards. For quantification, $\mathrm{IP}_{25}$ abundances were normalised according to a response factor, derived from a calibration of the $\mathrm{IP}_{25}$ standard to 9-octyl-8-heptadecene (Belt et al. 2012), and both $\mathrm{IP}_{25}$ and fatty acids were further normalised to quantities of internal standards and sample volume.

Lower and upper values for the $\mathrm{iPOCi}_{\mathrm{IP}} \mathrm{ISi}_{\mathrm{i}}(\mathrm{g}: \mathrm{g})$ ratio were calculated from bottom ice sampled in Resolute Passage on the 23 and 27 May 2012 (see Discussion). Range estimates of iPOC concentration in individual seawater samples ( $\mathrm{iPOC}_{w}$ ) were obtained by multiplying $\mathrm{IP}_{25}$ concentrations measured in seawater $\left(\mathrm{IP}_{25 w}\right)$ with these lower and upper $\mathrm{iPOC}_{\mathrm{i}} / \mathrm{IP}_{25 \mathrm{i}}$ ratios determined from analysis of sea ice (Eq. 1). Temporal range estimates of $\mathrm{iPOC}_{\mathrm{w}}$ were derived from the lowest and highest individual values across the time series. 
Disclaimer: This is a pre-publication version. Readers are recommended to consult the full published version for accuracy and citation.

$$
\mathrm{iPOC}_{w}=\mathrm{IP}_{25 w} \times \frac{\mathrm{iPOC}_{i}}{\mathrm{IP}_{25 \mathrm{i}}}
$$

248

249 Percentage concentration estimates of iPOC in seawater ( $\mathrm{PPOC}_{\mathrm{w}}$ ) were calculated using Eq. 2.

$$
\% \mathrm{iPOC}_{w}=100 \times \frac{\mathrm{iPOC}_{\mathrm{w}}}{\mathrm{tPOC}_{w}}
$$

252

\section{Statistical analysis}

254 Mann-Whitney $U$-test was performed to assess significant differences between bottom

255 ice and seawater samples. Spearman's rank order correlation (r) was used to infer the strength

256 of associations between two variables. These statistical tests were carried out using R 3.1

257 software. 
Disclaimer: This is a pre-publication version. Readers are recommended to consult the full published version for accuracy and citation.

258

259

260

261

262

263

264

265

266

267

268

269

270

271

272

273

274

275

276

277

278

279

280

281

282

\section{Results}

\section{Measurements in sea ice}

Bottom $(0-3 \mathrm{~cm})$ sea ice temperature increased steadily throughout sampling from 2.2 to $-0.2^{\circ} \mathrm{C}$, while sea ice thickness reduced from $127-93 \mathrm{~cm}$ (Fig. 1a, b). The concentration of $\mathrm{iPOC}_{\mathrm{i}}$ was highest early on in the sampling period, on 23 and 31 May (99$72 \mathrm{mg} \mathrm{l}^{-1}$ ), corresponding to $64 \%$ of the total cumulative iPOC $_{\mathrm{i}}$ measured throughout sampling (Fig. 1c). Over the same dates, the stable carbon isotopic composition of $\mathrm{PPOC}_{\mathrm{i}}$ was relatively enriched in ${ }^{13} \mathrm{C}\left(\delta^{13} \mathrm{C}-7.7\right.$ to $-8.3 \%$ ) (Fig. $\left.1 \mathrm{~d}\right)$. iPOC $\mathrm{i}$ concentration was lower (14 $-2 \mathrm{mg} \mathrm{l}^{-1}$ ) after 4 June and remained low until the end of the sampling period. At the same time, a change in the isotopic composition of $\mathrm{PPOC}_{\mathrm{i}}\left(\delta^{13} \mathrm{C}-11.4\right.$ to $-23 \%$ ) was evident (Fig. 1c, d). Chl $a$ followed a similar trend to iPOC $(\mathrm{r}=0.93, \mathrm{p}=<0.01)$, such that initial concentrations $\left(1.3-0.9 \mathrm{mg} \mathrm{l}^{-1}\right)$ reduced substantially after 4 June $\left(0.1-0.003 \mathrm{mg} \mathrm{l}^{-1}\right)$ (Fig. 1e), although bottom ice protist composition did not change noticeably between 27 May and 21 June (Fig. 2). The two highest concentrations of $\mathrm{IP}_{25 \mathrm{i}}\left(45\right.$ and $26 \mu \mathrm{g}^{-1}$ ) occurred on 23 and 27 May, respectively, with much lower concentrations from 31 May to 21 June $(9-0.01$ $\left.\mu \mathrm{g}^{-1}\right)$. During the interval of highest $\mathrm{IP}_{25 \mathrm{i}}$, the $\mathrm{iPOC}_{\mathrm{i}} / \mathrm{IP}_{25 \mathrm{i}}$ ratio ranged from 2,167 to 3,224 (mean 2,695) and generally increased up to $6 \times 10^{5}$ thereafter (Fig. 3).

\section{Measurements in seawater}

Under-ice seawater exhibited relatively consistent hydrographic conditions from 2 $80 \mathrm{~m}$ ( -1.7 to $-1.8^{\circ} \mathrm{C}$ and 32.1 to 32.4 salinity) up to 13 June (Fig. 4). After 14 June, near surface water $(2-5 \mathrm{~m})$ temperature began to increase $\left(-1.5^{\circ} \mathrm{C}\right)$ and, by $23 \mathrm{June}$, this extended down to $40 \mathrm{~m}$, along with a reduction in salinity $(<32)$. Temperature increased further $\left(-1.4{ }^{\circ} \mathrm{C}\right)$, while salinity continued to decrease (31.5) at $2 \mathrm{~m}$ at the end of sampling (Fig. 4), which coincided with the lowest sea ice thickness $(<1 \mathrm{~m})$ (Fig. 1b). Concentrations 
283 of $\mathrm{tPOC}_{\mathrm{w}}$ measured across the time series were most variable at $2 \mathrm{~m}$ water depth (i.e. close to 284 the ice/water interface) (Fig. 5a; mean \pm SD; $0.19 \pm 0.12 \mathrm{mg} \mathrm{l}^{-1}$ ). Between 30 May and 7

285 June, $\mathrm{tPOC}_{\mathrm{w}}$ at $2 \mathrm{~m}$ water depth was relatively high (mean $\pm \mathrm{SD} ; 0.17 \pm 0.02 \mathrm{mg} \mathrm{l}^{-1}$ ),

286 coincident with a reduction in $\mathrm{iPOC}_{\mathrm{i}}\left(\right.$ Fig. 1c). A further increase in $\mathrm{PPOC}_{\mathrm{w}}$ at $2 \mathrm{~m}$ occurred

287 towards the end of sampling, reaching a maximum on $23 \mathrm{June}\left(0.48 \mathrm{mg} \mathrm{l}^{-1}\right)$, despite there

288 being no further reduction in $\mathrm{iPOC}_{\mathrm{i}}$. Importantly, the protist composition on 30 May at $2 \mathrm{~m}$ 289 was extremely similar $(r=0.99, \mathrm{p}=<0.01)$ to that of the overlying sea ice on 27 May (Fig.

290 2). In contrast, protist composition in $2 \mathrm{~m}$ water on 23 June was not well correlated to the 291 corresponding compositions in $2 \mathrm{~m}$ water on 30 May $(\mathrm{r}=0.28, \mathrm{p}=0.40)$ or the overlying sea 292 ice on 21 June $(r=0.37, p=0.26)$, largely due to an increase in unidentified flagellates (Fig. 293 2).

294 Throughout sampling, tPOC $_{\mathrm{w}}$ concentrations generally decreased with water depth (Fig. 5a). 295 From 22 May to 3 June (i.e. before the reduction of $\mathrm{iPOC}_{\mathrm{i}}$ in sea ice), the concentration of $296 \mathrm{tPOC}_{\mathrm{w}}$ was relatively low and less variable between $5-80$ m water depth (mean \pm SD; 0.07 $297 \pm 0.02 \mathrm{mg} \mathrm{l}^{-1}$ ) than at $2 \mathrm{~m}$. From 7 to 23 June, following the reduction of $\mathrm{iPOC}_{\mathrm{i}}$ in sea ice, $298 \mathrm{tPOC}_{\mathrm{w}}$ increased between 5 and $80 \mathrm{~m}\left(\right.$ mean $\left.\pm \mathrm{SD} ; 0.13 \pm 0.05 \mathrm{mg} \mathrm{l}^{-1}\right)$, with $\mathrm{tPOC}_{\mathrm{w}}(80 \mathrm{~m})$ 299 reaching $0.14 \mathrm{mg}^{-1}$ from 16 June. The chl $a$ concentration profile broadly paralleled tPOC $\mathrm{w}_{\mathrm{w}}$ 300 throughout $(\mathrm{r}=0.53, \mathrm{p}=<0.01 ;$ Fig. $5 \mathrm{~b})$ and was also most variable at $2 \mathrm{~m}$ (mean $\pm \mathrm{SD} ; 0.85$ $\left.301 \pm 0.51 \mu \mathrm{g} \mathrm{l}^{-1}\right)$. In contrast to $\mathrm{PPOC}_{\mathrm{w}}$, however, maximum chl $a$ occurred between 30 May and 3027 June (mean $\pm \mathrm{SD} ; 1.45 \pm 0.25 \mu \mathrm{g} \mathrm{l^{-1 }}$ ), coincident with a rapid reduction of iPOC $\mathrm{i}_{\mathrm{i}}$ and $\operatorname{chl} a$ 303 in sea ice (Fig. 1c, e). Fatty acid concentrations were more closely correlated to those of 304 tPOC $_{\mathrm{w}}(\mathrm{r}=0.66, \mathrm{p}=<0.01)$, while maximum values coincided with highest chl $a$ (Fig. 5c; 30 305 May; $7.7 \mu \mathrm{g} \mathrm{l}^{-1}$ ) and $\mathrm{tPOC}_{\mathrm{w}}\left(23 \mathrm{June} ; 6.7 \mu \mathrm{g}^{-1}\right)$. $\mathrm{IP}_{25}$ was identified in all water samples and, 306 like $\mathrm{tPOC}_{\mathrm{w}}$, exhibited greatest concentration variability at $2 \mathrm{~m}$ (mean $\pm \mathrm{SD} ; 24.0 \pm 19.7 \mathrm{ng} \mathrm{l}^{-}$ $30{ }^{1}$ ) (Fig. 5a, d). The highest $\mathrm{IP}_{25}$ concentration in water $\left(\mathrm{IP}_{25 \mathrm{w}}\right)$ was at $2 \mathrm{~m}$ (30 May; $67.4 \mathrm{ng} \mathrm{l^{- }}$ 
Disclaimer: This is a pre-publication version. Readers are recommended to consult the full published version for accuracy and citation.

$30{ }^{1}$ ) which coincided with the late May increase of $\mathrm{tPOC}_{\mathrm{w}}$ and $\operatorname{chl} a$ at the same depth. A 309 second, but less pronounced increase in $\mathrm{IP}_{25 \mathrm{w}}\left(20 \mathrm{June} ; 30.3 \mathrm{ng} \mathrm{l}^{-1}\right.$ ) was limited to a single 310 sampling date (Fig. 5d). Between 22 and 30 May, (i.e. prior to the release of iPOC from sea 311 ice), the mean $\mathrm{IP}_{25 \mathrm{w}}$ concentration from $5-80 \mathrm{~m}$ was $7.1 \pm 3.6 \mathrm{ng}^{-1}$ which then increased to $31212.0 \pm 4.1 \mathrm{ng} \mathrm{l}^{-1}$ from 3 to 23 June as $\mathrm{iPOC}_{\mathrm{i}}$ declined. In seawater, $\mathrm{IP}_{25 \mathrm{w}}$ was well correlated to chl $a(\mathrm{r}=0.80, \mathrm{p}=<0.01)$ and, to a certain extent, fatty acid $(\mathrm{r}=0.65, \mathrm{p}=<0.01)$, but poorly correlated to $\operatorname{PPCC}_{\mathrm{w}}(\mathrm{r}=0.33, \mathrm{p}=0.02)$.

\section{Calculated iPOC $\mathrm{C}_{\mathrm{w}}$ in seawater}

317 Concentrations of ice-derived POC in the water column ( $\left.\mathrm{iPOC}_{\mathrm{w}}\right)$ were obtained by 318 combining $\mathrm{IP}_{25}$ concentrations in seawater $\left(\mathrm{IP}_{25 \mathrm{w}}\right)$ with lower and upper values for $\mathrm{iPOC}_{\mathrm{i}} / \mathrm{IP}_{25 \mathrm{i}}$ 319 of 2,167 and 3,224, respectively (mean $=2,695)($ Eqn. 1$)$, in order to provide range estimates 320 (see Discussion). Using this approach, $\mathrm{iPOC}_{\mathrm{w}}$ concentrations across the sampling dates were 321 found to be most variable at $2 \mathrm{~m}\left(0.02-0.22 \mathrm{mg} \mathrm{l}^{-1}\right)$, with the maximum POOC $_{\mathrm{w}}$ estimate 322 occurring on 30 May (Fig. 6a). Prior to the reduction of $\mathrm{PPOC}_{\mathrm{i}}(22$ to $30 \mathrm{May}), \mathrm{POC}_{\mathrm{w}}$ 323 concentrations were lower (mean $\pm \mathrm{SD} ; 0.02 \pm 0.01 \mathrm{mg}^{-1}$ ) between $5-80 \mathrm{~m}$ compared to those at $2 \mathrm{~m}$ (Fig. 6a). Following the surface (2 m) iPOC ${ }_{\mathrm{w}}$ maximum (30 May), iPOC $\mathrm{w}_{\mathrm{w}}$ concentrations increased in the mid-water column $\left(5-25 \mathrm{~m}\right.$; mean $\left.\pm \mathrm{SD} ; 0.04 \pm 0.01 \mathrm{mg} \mathrm{l}^{-1}\right)$, yet remained low in the deeper water column $\left(50-80 \mathrm{~m}\right.$; mean $\left.\pm \mathrm{SD} ; 0.02 \pm 0.006 \mathrm{mg} \mathrm{l}^{-1}\right)$. 
Disclaimer: This is a pre-publication version. Readers are recommended to consult the full published version for accuracy and citation.

\section{Discussion}

Our discussion focuses on an assessment of whether the calculated concentrations of $\mathrm{iPOC}_{\mathrm{w}}$ and $\% \mathrm{iPOC}$ w represent realistic quantitative estimates of iPOC in seawater both numerically and within the context of a spring bloom. Such an evaluation can be divided into a number of key considerations.

Firstly, it was important to establish that our sea ice and seawater samples reflected the period of iPOC transfer from ice to the water column, as would be expected at the end of a spring sea ice bloom (Fortier et al. 2002, Leventer 2003, Lavoie et al. 2005, Forest et al. 2010, Arrigo 2014). Confirmation of this was achieved on the basis that highest $\mathrm{IP}_{25 \mathrm{i}}, \mathrm{iPOC}_{\mathrm{i}}$ and chl $a$ (all in ice) occurred at the beginning of the sampling interval, with $76 \%$ of the protists consisting of diatoms with intact chloroplasts. At the same time, the stable carbon isotopic composition of $\mathrm{iPOC}_{\mathrm{i}}$ was at its heaviest $\left(\delta^{13} \mathrm{C}=-7.7 \%\right)$, consistent with biomass formed within sea ice (Pineault et al. 2013). As the sampling interval progressed, concentrations of $\mathrm{IP}_{25 \mathrm{i}}, \mathrm{iPOC}_{\mathrm{i}}$ and chl $a$ rapidly declined as biomass was released from bottom ice, and remained low until the end of the sampling interval. Comparison of the timing of the decrease in $\mathrm{IP}_{25 \mathrm{i}}, \mathrm{iPOC}_{\mathrm{i}}$ and and chl $a$, with other spring blooms recorded previously from Resolute and the Amundsen Gulf (Michel et al. 1996, Belt et al. 2013b), provides further evidence that our period of sampling coincided with the decline of the sea ice algal bloom.

At the end of May, the iPOC material that was lost from the bottom ice appeared within the surface water. Thus, a sharp increase in $\mathrm{IP}_{25}$ concentration at $2 \mathrm{~m}$, together with an extremely similar $(\mathrm{r}=0.99, \mathrm{p}=<0.01)$ composition of protists to that in sea ice, demonstrated that parallel increases in $\mathrm{tPOC}_{\mathrm{w}}, \mathrm{chl} a$ and fatty acid concentrations could most likely be attributed to the transfer of iPOC from ice to the water. Although absolute surface ocean current velocities in Resolute Passage are typically ca. $10 \mathrm{~cm} \mathrm{~s}^{-1}$, and regularly up to $30 \mathrm{~cm} \mathrm{~s}^{-}$ 
Disclaimer: This is a pre-publication version. Readers are recommended to consult the full published version for accuracy and citation.

353

354

355

356

357

358

359

360

361

362

363

364

365

366

367

368

369

370

371

372

373

374

375

376

377

${ }^{1}$ or more (Marsden et al 1994, Mundy et al. 2014), the residual flow at $15 \mathrm{~m}$ is $<10 \mathrm{~cm} \mathrm{~s}^{-1}$, and averages $<4 \mathrm{~cm} \mathrm{~s}^{-1}$ (Marsden et al 1994). Since this corresponds to ca. $0.4 \mathrm{~km} \mathrm{~d}^{-1}$, it is also feasible that some of the constituents within the water column samples were present as a result of relatively small-scale advection. Therefore, our $\mathrm{POC}_{\mathrm{w}}$ data may reflect a combination of both local (autochthonous) and advected (allochthonous) material. In any case, the similarity between iPOC and $\mathrm{PPOC}_{\mathrm{w}}$ in terms of lipid and protist composition provides evidence for their consistency in sea ice from the wider geographical region.

Clarification of this consistency could potentially be achieved through examination of sea ice samples with greater spatial coverage. As sea ice thickness declined, an under-ice bloom began to occur towards the end of the sampling period (Fig. 5). However, while this later under-ice bloom was also evident in $\mathrm{tPOC}_{\mathrm{w}}$, chl $a$ and fatty acid profiles, $\mathrm{IP}_{25 \mathrm{w}}$ did not increase at this time. Additionally, the proportion of pennate diatoms declined from 71 to $14 \%$ and unidentifiable flagellates increased from 12 to $47 \%$ compared to surface water at the end of May (Fig. 2). Accordingly, our data are more consistent with pelagic productivity, rather than further ice-released POC at this time.

Combined, the profiles of $\mathrm{IP}_{25}, \mathrm{POC}, \operatorname{chl} a$, fatty acid, stable isotopes and protist composition confirmed that our samples corresponded to a period where iPOC was transferred from sea ice to the water column. The source selectivity of $\mathrm{IP}_{25}$ permitted the identification of input of both $\mathrm{iPOC}_{\mathrm{w}}$ and $\mathrm{pPOC}_{\mathrm{w}}$ based on increases and decreases in $\mathrm{IP}_{25 \mathrm{w}}$ concentrations, relative to POC, $\operatorname{chl} a$ and fatty acid in water. Since the sampling site remained ice covered, throughout the period of sampling (ice $>90 \mathrm{~cm}$ thick), we attribute increases in $\mathrm{pPOC}_{\mathrm{w}}$ toward the end of the sampling interval to an under-ice phytoplankton, rather than open water bloom (Fortier et al. 2002, Arrigo et al. 2014, Mundy et al. 2014). As such, the sample set represents a useful template for testing our hypotheses against two contrasting source inputs of POC. 
Disclaimer: This is a pre-publication version. Readers are recommended to consult the full published version for accuracy and citation.

378

379

380

381

382

383

384

385

386

387

388

389

390

391

392

393

394

395

396

397

398

399

400

401

402

Secondly, to obtain quantitative estimates of iPOC within the water column, it was necessary to determine a value (or range) for the $\mathrm{iPOC}_{\mathrm{i}} / \mathrm{IP}_{25 \mathrm{i}}$ ratio that could be considered representative of iPOC in sea ice. One approach to achieving this would be through direct measurement from cultures of $\mathrm{IP}_{25}$ producing diatoms. However, since such data (or cultures) are not currently available, we instead first calculated a range of theoretical iPOC/IP 25 ratios using data from cultures of diatoms that produce other $\mathrm{HBI}$ lipids similar to $\mathrm{IP}_{25}$. To do this, we took the measured TOC/HBI ratio in cultures of Haslea ostrearia (TOC/HBI ca. 70; Brown et al. 2014c) and Berkeleya rutilans (TOC/HBI ca. 50; Brown et al. 2014b) and combined these with the proportion of $\mathrm{IP}_{25}$-producing species in our samples $(0.5-3.2 \%)$; the latter being consistent with values reported previously for Arctic sea ice $(0.3-5 \%$; Belt et al. 2007, 2013b, Belt \& Müller 2013, Brown et al. 2014c). Using this method, we estimated a theoretical range of $\mathrm{iPOC}_{\mathrm{IP}} 25$ ratios in ice to be between ca. $10^{3}$ and $10^{4}$. A complementary (and likely more accurate) approach for obtaining a suitable iPOC/IP 25 ratio, however, is one that uses concentration data specific to the location and timing of sampling, especially considering how sea ice and the underlying water column are coupled. Since it is also likely that the $\mathrm{iPOC}_{\mathrm{i}} / \mathrm{IP}_{25 \mathrm{i}}$ ratio may be sensitive to the sampling interval (as was the case here) and might, potentially, also be quite variable in sea ice from other locations or seasons/years, we decided to determine $\mathrm{iPOC}_{\mathrm{i}} / \mathrm{IP}_{25 \mathrm{i}}$ ratio from sea ice, rather than from cultures. In the current study, we used $\mathrm{PPOC}_{\mathrm{i}} / \mathrm{IP}_{25 \mathrm{i}}$ values for sea ice samples collected from 23 to 27 May to provide lower and upper estimates of PPOC $_{\mathrm{w}}$ since these corresponded to samples with the highest overall $\mathrm{iPOC}_{\mathrm{i}}$ and $\mathrm{IP}_{25}$, the majority of protists $(>70 \%)$ comprised diatoms, and the stable isotopic composition (mean $\delta^{13} \mathrm{C}=-8.2 \%$ ) of $\mathrm{iPOC}_{\mathrm{i}}$ all confirmed that the majority (if not all) of the biomass was produced within sea ice (Pineault et al. 2013). Significantly, the mean value of $\mathrm{iPOC}_{\mathrm{i}} / \mathrm{IP}_{25 \mathrm{i}}$ in sea ice from 23 to $27 \mathrm{May}$ (ca. $2.7 \times 10^{3}$ ) falls 
Disclaimer: This is a pre-publication version. Readers are recommended to consult the full published version for accuracy and citation.

403

404

405

406

407

408

409

410

411

412

413

414

415

416

$417 \quad \mathrm{IP}_{25}$ could be quantified in all water samples, these values covered all stages of the release of

$418 \mathrm{iPOC}_{\mathrm{i}}$ to the water column, with estimates of $\mathrm{iPOC}_{\mathrm{w}}$ and $\% \mathrm{POC}_{\mathrm{w}}$ ranging from $0.01-0.22$

$419 \mathrm{mg} \mathrm{l}^{-1}$ and $6-125 \%$, respectively. To the best of our knowledge, there have been no previous reports of equivalent data with similar depth and temporal resolution to compare with our findings, but we are able to evaluate the numerical values, to some extent, on the basis of

422 theoretical limits and an understanding of the system under study (viz. the transfer of iPOC 423 into the water column following the spring bloom). For example, since $\mathrm{PPOC}_{\mathrm{w}}$ cannot exceed the $\mathrm{tPOC}_{\mathrm{w}}$ within the same sample, $\mathrm{tPOC}_{\mathrm{w}}$ concentrations provide an upper limit for $\mathrm{POC}_{\mathrm{w}}$ estimates in all samples. Significantly, therefore, we note that nearly all \%iPOC $\mathrm{C}_{\mathrm{i}}$ values were $<100 \%$. Exceptionally the highest values we found ranged between $85-125 \%$ (mean 105\%),

427 based on the upper and lower limits of the ratio. This finding was consistent with our 
Disclaimer: This is a pre-publication version. Readers are recommended to consult the full published version for accuracy and citation.

428

429

430

431

432

433

434

435

436

437

438

439

440

441

442

443

444

445

446

447

448

449

450

451

452 observation of overall protist composition in seawater (30 May) being almost identical ( $\mathrm{p}=$ $<0.01)$ to that of sea ice (27 May). Similarly, the percentage of $\mathrm{IP}_{25}$ producers to total diatoms $(1.3 \%)$ and total protists $(0.97 \%)$ in water on 30 May, was extremely similar (1.4 and $1.03 \%)$ to that found in sea ice on 27 May. Collectively, these observations suggest that the majority of the $\mathrm{POCC}_{\mathrm{w}}$ in the upper water depth was derived from iPOC; a conclusion also arrived at by Michel et al. (1996) who used a carbon budget model based on pigment concentrations to estimate that iPOC corresponded to $98-138 \%$ of upper $0-15$ m water column POC, and coincided with iPOC loss from bottom ice.

In addition to finding that virtually all of the calculated $\% \mathrm{iPOC}_{\mathrm{i}}$ values were $<100 \%$, we also identified two statistically different (Wilcoxon ranked sum $p=<0.001$ ) and contextually relevant zones (Fig. 6b) in the water column on the basis of the entire estimated $\% \mathrm{iPOC}_{\mathrm{w}}$ dataset. The high spatial and temporal resolution of our data enabled us to determine that these zones were partially stratified, as well as being temporally divided in early June. The first of these zones, Zone-a, corresponded to the first half of sampling (i.e. 22 May to 11 June) and from $2-50 \mathrm{~m}$ and contained $\mathrm{PPOC}_{\mathrm{w}}$ that ranged from 9 to $125 \%$ of $\mathrm{tPOC}_{\mathrm{w}}$, but with mean lower and upper estimates (37 - 55\%) indicating comparable contributions of $\mathrm{iPOC}_{w}$ and other POC from additional sources. In contrast, Zone-b comprised samples where $\% \mathrm{iPOC}_{\mathrm{w}}$ ranged from $6-52 \%$ and was defined by all samples at $80 \mathrm{~m}$ and all depths after 16 June to the end of sampling and included the onset of the underice bloom at the end of the sampling period. We note, however, that the major difference between these zones was due to a more significant difference $(p=0.003)$ in $\mathrm{tPOC}_{\mathrm{w}}$ between the two zones rather than differences in the estimated $\mathrm{iPOC}_{\mathrm{w}}$ concentration $(\mathrm{p}=0.08)$, presumably due to increased POC from the growing under-ice bloom observed here towards the end of the sampling interval. Previous studies have identified that the bloom period consists of changes in POC export in relation to pre- and post-bloom conditions, based on 
Disclaimer: This is a pre-publication version. Readers are recommended to consult the full published version for accuracy and citation.

453

454

455

456

457

458

459

460

461

462

463

464

465

466

467

468

469

470

471

472

473

474

475

476

477

quantitative measurements of parameters such as POC (Michel et al. 1996, Fortier et al. 2002,

Forest et al. 2008, Juul-Pedersen et al. 2008). For example, Michel et al. (1996) reported a

significant difference between pre- and post-iPOC input in Resolute. This transition from iPOC to pPOC dominance is very important in the Arctic, and models have been created in an attempt to quantify the relative importance of iPOC, in particular (Michel et al. 1996, Deal et al. 2011, Forest et al. 2011b). For example, Forest et al. (2011b) integrated data spanning spring-summer in the Amundsen Gulf to estimate that ice algae contributed 6\% of the total primary production throughout this time. In the current study, our sampling has provided further insights into the temporal evolution of iPOC to pPOC on a more highly resolved temporal scale which is useful for gaining a better understanding of this important springtime transition.

Finally, our estimated iPOC $\mathrm{w}_{\mathrm{w}}$ concentrations have been made on the assumptions that the measured range in the $\mathrm{iPOC}_{\mathrm{i}} / \mathrm{IP}_{25 \mathrm{i}}$ ratio, determined through analysis of sea ice samples from a single location, are both representative of Resolute Passage (see earlier) and remained unaltered in seawater. Our data support these assumptions, with additional contributions to tPOC resulting in an enhancement of $\mathrm{tPOC}_{\mathrm{w}} / \mathrm{IP}_{25 \mathrm{w}}$, and a decrease in $\% \mathrm{iPOC}_{\mathrm{w}}$, as predicted. Nevertheless, we believe it valuable to consider the impacts of a number of other theoretical scenarios on the derived $\mathrm{iPOC}_{\mathrm{w}}$ and $\% \mathrm{iPOC}_{\mathrm{w}}$ values.

The first of these alternative scenarios represents a sea ice dominated system, where iPOC is transferred to the water column with no additional contribution of POC from other sources. In this setting, an unaltered $\mathrm{iPOC}_{\mathrm{i}} / \mathrm{IP}_{25 \mathrm{i}}$ ratio would lead to $\% \mathrm{iPOC}_{\mathrm{w}}$ being consistently $100 \%$ of $\mathrm{tPOC}_{\mathrm{w}}$ (or very close to this value). In practice, such an observation was confined to a single $2 \mathrm{~m}$ water sample, and this coincided with the timing of maximum delivery of iPOC from melting sea ice (30 May). In addition, the consistency in the protist composition of the sea ice and water samples at this time also suggested that the majority (if 
Disclaimer: This is a pre-publication version. Readers are recommended to consult the full published version for accuracy and citation.

478

479

480

481

482

483

484

485

486

487

488

489

490

491

492

493

494

495

496

497

498

499

500

501

502

not all) of the POC in the surface water was derived from sea ice biota; a conclusion arrived at previously for upper water in Resolute Passage (Michel et al. 1996). However, the majority of our $\% \mathrm{iPOC}_{\mathrm{w}}$ estimates were less than $100 \%$, and as low as $6 \%$, indicative, therefore, of a second scenario, whereby iPOC is transferred to the water column where it becomes combined with additional sources of $\mathrm{POC}$ with an increase to the $\mathrm{PPOC}_{\mathrm{w}} / \mathrm{IP}_{25 \mathrm{w}}$ ratio and a reduction in $\% \mathrm{iPOC}_{\mathrm{w}}$, consistent with the range observed (i.e. $6-125 \%$ ). Of course, pending further investigation, the potential alteration of the iPOC composition following release from ice, resulting from, for example, increased production of exopolymeric substances (e.g. Underwood et al. 2013), cannot be ignored, especially as this would also lead to increases in the $\mathrm{PPOC}_{\mathrm{w}} / \mathrm{IP}_{25 \mathrm{w}}$ ratio, regardless of any contributions from $\mathrm{pPOC}_{\mathrm{w}}$.

A third scenario considers the impact of preferential degradation of $\mathrm{IP}_{25 \mathrm{w}}$ over other components within iPOC, which might potentially occur both with and without additional POC input. As a consequence of such a degradation process, a modified $\mathrm{iPOC}_{\mathrm{i}} / \mathrm{IP}_{25 \mathrm{i}}$ ratio would result in substantial underestimates of $\% \mathrm{iPOC}_{\mathrm{w}}$. In an extreme case, such a scenario may even prevent the calculation of $\mathrm{iPOC}_{\mathrm{w}}$ if $\mathrm{IP}_{25 \mathrm{w}}$ became sufficiently degraded to prevent detection. In practice, however, $\mathrm{IP}_{25}$ was readily quantified in all samples. On the other hand, it is not possible to discount this scenario entirely since $\% \mathrm{POC}_{\mathrm{w}}$ estimates covered a broad range, with some values less than $10 \%$. However, it has been previously shown that $\mathrm{IP}_{25}$ is far less reactive than some other components of POC, including fatty acids and $\operatorname{chl} a$, under laboratory conditions designed to represent the euphotic zone (Rontani et al. 2011). As a consequence, therefore, we suggest that preferential degradation of $\mathrm{IP}_{25}$ compared to other components of POC is an unlikely scenario. In contrast, a fourth scenario, whereby iPOC degrades at a higher rate compared to $\mathrm{IP}_{25}$, likely represents a more realistic modifier of the $\mathrm{iPOC}_{\mathrm{i}} / \mathrm{IP}_{25 \mathrm{i}}$ ratio, especially given the enhanced reactivity of some components of iPOC (e.g. fatty acids) to processes such as oxidation in the euphotic zone (Rontani et al. 2003b, Rontani 
Disclaimer: This is a pre-publication version. Readers are recommended to consult the full published version for accuracy and citation.

503

504

505

506

507

508

509

510

511

512

513

514

515

516 517 consistent (Brown et al., 2014c).

518

519

520

521

522

523

524

525

526

527

(1)

et al. 2011, Rontani et al. 2012). However, the primary degradation processes tend to result in relatively minor alterations to chemical structures, rather than complete degradation

(mineralisation). For example, the primary photo-oxidation of POC components such as fatty acids leads to the formation of structurally similar hydroperoxides (Rontani et al. 2003a, Rontani et al. 2012), which would not have significant impacts on $\mathrm{iPOC}_{\mathrm{IP}} 25$ ratios. In any case, any enhanced loss of $\mathrm{iPOC}_{\mathrm{w}}$ (relative to $\mathrm{IP}_{25}$ ) would result in overestimates of $\% \mathrm{iPOC}_{\mathrm{w}}$ and, in particular, values that are in a large excess of $100 \%$, which is not the case. Of course, it is possible that losses in $\mathrm{PPOC}_{\mathrm{i}}$ may be compensated for by the addition of POC from other sources, but this seems unlikely given the generally similar composition, and thus reactivity, of POC derived from different sources. Finally, changes in the protist composition in favour of $\mathrm{IP}_{25}$ producers, or further production of $\mathrm{IP}_{25}$ within the water column, would also result in overestimates of $\% \mathrm{iPOC}$. However, this would also result in $\% \mathrm{iPOC}_{\mathrm{w}}$ values $>100 \%$ and, in any case, there have been no reports of $\mathrm{IP}_{25}$ in the pelagic environment. We also note that the $\% \mathrm{IP}_{25}$-producing diatoms in mixed Arctic sea ice diatom assemblages is reasonably

In conclusion, we describe a novel biomarker-based approach that not only provides a means of identifying the transfer of POC from sea ice to the water column, but also allows quantification of concentrations and percentage contributions of ice-algae derived POC in seawater. We present these outcomes from a case study location (Resolute Passage) that has a well-defined spring sea ice melt and algal bloom. In contrast to the limited number of previous studies, which are temporally and spatially integrated, the current approach also permits higher resolution assessments of ice-derived POC to be conducted which will enable the evaluation of changes in source POC to be investigated in more detail. As a next stage in the development of this approach, it will be important to establish the variability in, and 
Disclaimer: This is a pre-publication version. Readers are recommended to consult the full published version for accuracy and citation.

528 influences over, the $\mathrm{iPOC}_{\mathrm{i}} / \mathrm{IP}_{25 \mathrm{i}}$ ratio, together with the impacts that these have on

529 quantitative estimates of ice-derived organic matter in the water column.

530

531 
Disclaimer: This is a pre-publication version. Readers are recommended to consult the full published version for accuracy and citation.

532 Acknowledgements.

533 This research was funded by the award of a Research Project Grant from the Leverhulme

534 Trust to S.B. and T.B. (PDRF), the Natural Sciences and Engineering Research Council of

535 Canada to C.J.M., M.G. and M.L. and Fonds de recherche du Québec - Nature et

536 Technologies to the Québec-Océan strategic cluster and by financial support from the

537 Canadian Museum of Nature to M.P. and Canada Economic Development to M.G. Field

538 support was provided by the Polar Continental Shelf Program of Natural Resources Canada.

539 The authors thank Marjolaine Blais, Virginie Galindo, Mathew Gale, Alexis Burt, Nicolas-

540 Xavier Geilfus and Margaux Gourdal for assistance in the field; Sylvie Lessard for protist

541 identification and enumeration; Mathieu Babin and Marjolaine Blais for POC and stable

542 carbon isotope analysis; and Pascal Guillot for CTD data processing. We are grateful to three

543 anonymous reviewers for providing helpful comments on a previous version of this

544 manuscript. This is a contribution to the research programs of the Arctic Science Partnership

545 (ASP), the Canada Excellence Research Chair unit at the Centre for Earth Observation

546 Science, ArcticNet and Québec-Océan. 
Disclaimer: This is a pre-publication version. Readers are recommended to consult the full published version for accuracy and citation.

\section{LITERATURE CITED}

548 Arrigo KR (2014) Sea ice ecosystems. Annu Rev Mar Sci 6:439-467

549 Arrigo KR, Mock T, Lizotte MP (2010) Primary producers and sea ice. In: Thomas DN, Dieckmann GS (eds) Sea ice, $2^{\text {nd }}$ ed. Wiley-Blackwell, Oxford, p 283-325

551

552

553

554

555

556

557

558

559

560

561

562

563

564

565

566

567

568

569

570

571

572

573

Arrigo KR, Perovich DK, Pickart RS, Brown ZW, van Dijken GL, Lowry KE, Mills MM, Palmer MA, Balch WM, Bates NR, Benitez-Nelson CR, Brownlee E, Frey KE, Laney SR, Mathis J, Matsuoka A, Greg Mitchell B, Moore GWK, Reynolds RA, Sosik HM, Swift JH (2014) Phytoplankton blooms beneath the sea ice in the Chukchi sea. Deep-Sea Res II 105:1-16

Belt ST, Brown TA, Ampel L, Cabedo-Sanz P, Fahl K, Kocis JJ, Massé G, Navarro-Rodriguez A, Ruan J, Xu Y (2013a) An inter-laboratory investigation of the Arctic sea ice biomarker proxy $\mathrm{IP}_{25}$ in marine sediments: key outcomes and recommendations. Clim Past Discuss 9:52635298

Belt ST, Brown TA, Navarro-Rodriguez A, Cabedo-Sanz P, Tonkin A, Ingle R (2012) A reproducible method for the extraction, identification and quantification of the Arctic sea ice proxy $\mathrm{IP}_{25}$ from marine sediments. Anal Methods 4:705-713

Belt ST, Brown TA, Ringrose AE, Cabedo-Sanz P, Mundy CJ, Gosselin M, Poulin M (2013b) Quantitative measurement of the sea ice diatom biomarker $\mathrm{IP}_{25}$ and sterols in Arctic sea ice and underlying sediments: further considerations for palaeo sea ice reconstruction. Org Geochem 62:33-45

Belt ST, Massé G, Rowland SJ, Poulin M, Michel C, LeBlanc B (2007) A novel chemical fossil of palaeo sea ice: $\mathrm{IP}_{25}$. Org Geochem 38:16-27

Belt ST, Massé G, Vare LL, Rowland SJ, Poulin M, Sicre M-A, Sampei M, Fortier L (2008) Distinctive ${ }^{13} \mathrm{C}$ isotopic signature distinguishes a novel sea ice biomarker in Arctic sediments and sediment traps. Mar Chem 112:158-167

Belt ST, Müller J (2013) The Arctic sea ice biomarker IP ${ }_{25}$ : a review of current understanding, recommendations for future research and applications in palaeo sea ice reconstructions. Quat Sci Rev 79:9-25 
Disclaimer: This is a pre-publication version. Readers are recommended to consult the full published version for accuracy and citation.

574 Brown TA (2011) Production and preservation of the Arctic sea ice diatom biomarker $\mathrm{IP}_{25} . \mathrm{PhD}$ Thesis, University of Plymouth

576

577

578

579

580

581

582

583

584

585

586

587

588

589

590

591

592

593

594

595

596

597

598

599

carbon contributions to the Arctic ecosystem: A case study using highly branched isoprenoid lipid biomarkers in Cumberland Sound ringed seals. Limnol Oceanogr 59:1581-1589

Brown TA, Belt ST (2012a) Closely linked sea ice-pelagic coupling in the Amundsen Gulf revealed by the sea ice diatom biomarker $\mathrm{IP}_{25}$. J Plankton Res 34:647-654

Brown TA, Belt ST (2012b) Identification of the sea ice diatom biomarker $\mathrm{IP}_{25}$ in Arctic benthic macrofauna: Direct evidence for a sea ice diatom diet in Arctic heterotrophs. Polar Biol $35: 131-137$

Brown TA, Belt ST, Cabedo-Sanz P (2014b) Identification of a novel di-unsaturated $\mathrm{C}_{25}$ highly branched isoprenoid in the marine tube-dwelling diatom Berkeleya rutilans. Environ Chem Lett 12:455-460

Brown TA, Belt ST, Philippe B, Mundy CJ, Massé G, Poulin M, Gosselin M (2011) Temporal and vertical variations of lipid biomarkers during a bottom ice diatom bloom in the Canadian Beaufort Sea: Further evidence for the use of the $\mathrm{IP}_{25}$ biomarker as a proxy for spring Arctic sea ice. Polar Biol 34:1857-1868

Brown TA, Belt ST, Piepenburg D (2012) Evidence for a pan-Arctic sea-ice diatom diet in Strongylocentrotus spp. Polar Biol 35:1281-1287

Brown TA, Belt ST, Tatarek A, Mundy CJ (2014c) Source identification of the Arctic sea ice proxy IP $_{25}$. Nat Commun 5:4197, doi:10.1038/ncomms5197

Brown TA, Yurkowski DJ, Ferguson SH, Alexander C, Belt ST (2014d) H-Print: a new chemical fingerprinting approach for distinguishing primary production sources in Arctic ecosystems. Environ Chem Lett 12:387-392

Budge S, Wooller M, Springer A, Iverson S, McRoy C, Divoky G (2008) Tracing carbon flow in an arctic marine food web using fatty acid-stable isotope analysis. Oecologia 157:117-129 
Disclaimer: This is a pre-publication version. Readers are recommended to consult the full published version for accuracy and citation.

600 Deal C, Jin M, Elliott S, Hunke E, Maltrud M, Jeffery N (2011) Large-scale modeling of primary

601

602 production and ice algal biomass within arctic sea ice in 1992. J Geophys Res 116:C07004,

603 Dieckmann GS, Hellmer HH (2010) The importance of sea ice: An overview. In: Thomas D, Dieckmann S (eds) Sea ice, 2nd edn. Wiley-Blackwell, Oxford, p 1-22

Forest A, Bélanger S, Sampei M, Sasaki H, Lalande C, Fortier L (2010) Three-year assessment of particulate organic carbon fluxes in Amundsen Gulf (Beaufort Sea): Satellite observations and sediment trap measurements. Deep-Sea Res I 57:125-142

Forest A, Galindo V, Darnis G, Pineault S, Lalande C, Tremblay J-E, Fortier L (2011a) Carbon biomass, elemental ratios $(\mathrm{C}: \mathrm{N})$ and stable isotopic composition $\left(\delta^{13} \mathrm{C}, \delta^{15} \mathrm{~N}\right)$ of dominant calanoid copepods during the winter-to-summer transition in the Amundsen Gulf (Arctic Ocean). J Plankton Res 33:161-178

Forest A, Sampei M, Makabe R, Sasaki H, Barber DG, Gratton Y, Wassmann P, Fortier L (2008) The annual cycle of particulate organic carbon export in Franklin Bay (Canadian Arctic): Environmental control and food web implications. J Geophys Res 113:C03S05,

616 Forest A, Tremblay J-É, Gratton Y, Martin J, Gagnon J, Darnis G, Sampei M, Fortier L, Ardyna M, Gosselin M, Hattori H, Nguyen D, Maranger R, Vaqué D, Marrasé C, Pedrós-Alió C, Sallon A, Michel C, Kellogg C, Deming J, Shadwick E, Thomas H, Link H, Archambault P, Piepenburg D (2011b) Biogenic carbon flows through the planktonic food web of the Amundsen Gulf (Arctic Ocean): A synthesis of field measurements and inverse modeling analyses. Prog Oceanogr 91:410-436

622 Fortier M, Fortier L, Michel C, Legendre L (2002) Climatic and biological forcing of the vertical flux of biogenic particles under seasonal Arctic sea ice. Mar Ecol-Prog Ser 225:1-16

624 Garrison DL, Buck KR (1986) Organism losses during ice melting: A serious bias in sea ice 
Disclaimer: This is a pre-publication version. Readers are recommended to consult the full published version for accuracy and citation.

626 Gosselin M, Legendre L, Therriault JC, Demers S, Rochet M (1986) Physical control of the horizontal patchiness of sea ice microalgae. Mar Ecol-Prog Ser 29:289-298

628 Juul-Pedersen T, Michel C, Gosselin M, Seuthe L (2008) Seasonal changes in the sinking export of 629 particulate material under first-year sea ice on the Mackenzie Shelf (western Canadian Arctic). Mar Ecol-Prog Ser 353:13-25

Knies J, Cabedo-Sanz P, Belt ST, Baranwal S, Fietz S, Rosell-Melé A (2014) The emergence of modern sea ice cover in the Arctic Ocean. Nat Commun 5:5608, doi:10.1038/ncomms6608

Lavoie D, Denman K, Michel C (2005) Modelling ice algal growth and decline in a seasonally icecovered region of the Arctic (Resolute Passage, Canadian Archipelago). J Geophys Res 110:C11009, doi:10.1029/2005JC002922

Leu E, Søreide JE, Hessen DO, Falk-Petersen S, Berge J (2011) Consequences of changing sea-ice cover for primary and secondary producers in the European Arctic shelf seas: Timing, quantity, and quality. Prog Oceanogr 90:18-32

Leventer A (2003) Chapter 10 - Particulate flux from sea ice in polar waters. In: Thomas DN,

642 Lund JWG, Kipling C, Le Cren ED (1958) The inverted microscope method of estimating algal numbers and the statistical basis of estimations by counting. Hydrobiologia 11:143-170

Marsden, R. F., R. Paquet, and R. G. Ingram. 1994. Currents under land-fast ice in the Canadian Arctic Archipelago Part 1: Vertical velocities. Journal of Marine Research. 52: 1017-1036.

646 Michel C, Legendre L, Ingram RG, Gosselin M, Levasseur M (1996) Carbon budget of sea-ice algae in spring: Evidence of a significant transfer to zooplankton grazers. J Geophys Res $101: 18345-18360$

Michel C, Nielsen TG, Nozais C, Gosselin M (2002) Significance of sedimentation and grazing by ice micro- and meiofauna for carbon cycling in annual sea ice (northern Baffin Bay). Aquat

652 Morata N, Renaud PE (2008) Sedimentary pigments in the western Barents Sea: A reflection of pelagic-benthic coupling? Deep-Sea Res II 55:2381-2389 
Disclaimer: This is a pre-publication version. Readers are recommended to consult the full published version for accuracy and citation.

654 Mundy CJ, Gosselin M, Gratton Y, Brown K, Galindo V, Campbell K, Levasseur M, Barber D, Papakyriakou T, Belanger S (2014) Role of environmental factors on phytoplankton bloom initiation under landfast sea ice in Resolute Passage, Canada. Mar Ecol-Prog Ser 497:39-49

Munro DR, Dunbar RB, Mucciarone DA, Arrigo KR, Long MC (2010) Stable isotope composition of dissolved inorganic carbon and particulate organic carbon in sea ice from the Ross Sea, Antarctica. J Geophys Res 115:C09005, doi:10.1029/2009JC005661

Parsons T, Maita Y, Lalli C (1984) A manual of chemical and biological methods for seawater analysis. Pergamon Press, Totronto

Pineault S, Tremblay J-É, Gosselin M, Thomas H, Shadwick E (2013) The isotopic signature of particulate organic $\mathrm{C}$ and $\mathrm{N}$ in bottom ice: Key influencing factors and applications for tracing the fate of ice-algae in the Arctic Ocean. J Geophys Res 118:287-300

Renaud PE, Riedel A, Michel C, Morata N, Gosselin M, Juul-Pedersen T, Chiuchiolo A (2007) Seasonal variation in benthic community oxygen demand: A response to an ice algal bloom in the Beaufort Sea, Canadian Arctic? J Mar Syst 67:1-12

Rontani J-F, Belt ST, Vaultier F, Brown TA (2011) Visible light induced photo-oxidation of highly branched isoprenoid (HBI) alkenes: Significant dependence on the number and nature of double bonds. Org Geochem 42:812-822

Rontani J-F, Koblizek M, Beker B, Bonin P, Kobler Z (2003a) On the origin of cis-vaccenic acid photodegradation products in the marine environment Lipids 38:1085-1092

Rontani J-F, Rabourdin A, Marchand D, Aubert C (2003b) Photochemical oxidation and autoxidation of chlorophyll phytyl side chain in senescent phytoplanktonic cells: Potential sources of several acyclic isoprenoid compounds in the marine environment. Lipids 38:241-254 (2012) Intense photooxidative degradation of planktonic and bacterial lipids in sinking particles collected with sediment traps across the Canadian Beaufort Shelf (Arctic Ocean). Biogeosciences 9:4787-4802 
Disclaimer: This is a pre-publication version. Readers are recommended to consult the full published version for accuracy and citation.

680 Søreide JE, Leu E, Berge J, Graeve M, Falk-Petersen S (2010) Timing of blooms, algal food quality and Calanus glacialis reproduction and growth in a changing Arctic. Glob Change Biol

682 $16: 3154-3163$

683 Tremblay J-É, Michel C, Hobson KA, Gosselin M, Price NM (2006) Bloom dynamics in early opening waters of the Arctic Ocean. Limnol Oceanogr 51:900-912

685

Underwood GJC, Aslam SN, Michel C, Niemi A, Norman L, Meiners KM, Laybourn-Parry J, Paterson H, Thomas DN (2013) Broad-scale predictability of carbohydrates and exopolymers in Antarctic and Arctic sea ice. P Natl Acad Sci USA 110:15734-15739

688 Volkman JK, Barrett SM, Blackburn SI, Mansour MP, Sikes El, Gelin F (1998) Microalgal 689 biomarkers: A review of recent research developments. Org Geochem 29:1163-1179 characteristics of sea ice and pelagic particulate organic matter in the Bering Sea: tools for 
Disclaimer: This is a pre-publication version. Readers are recommended to consult the full published version for accuracy and citation.

\section{Figure legends}

697 Fig. 1. Time series of (a) temperature and (b) total ice thickness, (c) particulate organic

698 carbon $\left(\mathrm{iPOC}_{\mathrm{i}}\right),(\mathrm{d})$ carbon stable isotope composition $\left(\delta^{13} \mathrm{C}\right),(\mathrm{e})$ chlorophyll $a(\mathrm{Chl} a)$, and

699 (f) sea ice diatom biomarker $\operatorname{IP}_{25}\left(\mathrm{IP}_{25 \mathrm{i}}\right)$ measured in the bottom $0-3 \mathrm{~cm}$ of sea ice in

700 Resolute Passage from 23 May to 21 June 2012

701

702

Fig. 2. Relative abundance of protists in the bottom $3 \mathrm{~cm}$ of sea ice and in seawater $(2 \mathrm{~m})$ in 703

Resolute Passage at the end of May and towards the end of June.

704

705

Fig. 3. Time series of measurements in the bottom $3 \mathrm{~cm}$ of sea ice in Resolute Passage from

706

23 May to 21 June 2012. Bar: $\mathrm{PPOC}_{\mathrm{i}}, \%$ relative abundance of the total $\mathrm{iPOC}_{\mathrm{i}}$ measured in sea

707 ice during the sampling interval. Scatter: $\mathrm{PPOC}_{\mathrm{i}} / \mathrm{IP}_{25 \mathrm{i}}(\mathrm{g}: \mathrm{g})$. Cross represents outlier

708

Fig. 4. Time series of water column (a) temperature and (b) salinity in Resolute Passage from

71021 May to 23 June 2012. Data from 36 hydrocasts (black dots) were interpolated and plotted

in Ocean Data View v. 4.6.1. Schlitzer, R., Ocean Data View, http://odv.awi.de, 2015.

712

713 Fig. 5. Time series of water column (a) particulate organic carbon ( $\operatorname{tPOC}_{\mathrm{w}}$ ), (b) chlorophyll $a$,

714 (c) $\mathrm{C}_{14: 0}$ fatty acid, and (d) the sea ice diatom biomarker $\operatorname{IP}_{25}\left(\operatorname{IP}_{25} \mathrm{w}\right)$ in Resolute Passage from

71521 May to 23 June 2012. Data from 54 discrete samples were interpolated and plotted using

716 Ocean Data View v. 4.6.1. Schlitzer, R., Ocean Data View, http://odv.awi.de, 2015.

717

718 Fig. 6. Time series of water column (a) mean estimated concentrations of sea ice derived

719 particulate organic carbon $\left(\mathrm{iPOC}_{\mathrm{w}}\right)$, and (b) $\mathrm{iPOCw}$ as a proportion of total particulate 720 organic carbon $\left(\% \mathrm{iPOC}_{\mathrm{w}}\right)$. Black line divides zone-a and zone-b based on significantly 
Disclaimer: This is a pre-publication version. Readers are recommended to consult the full published version for accuracy and citation.

721 different $(\mathrm{p}=<0.001)$ concentrations of total particulate organic carbon (tPOC). Schlitzer, R.,

722 Ocean Data View, http://odv.awi.de, 2015. 
Disclaimer: This is a pre-publication version. Readers are recommended to consult the full published version for accuracy and citation.

723
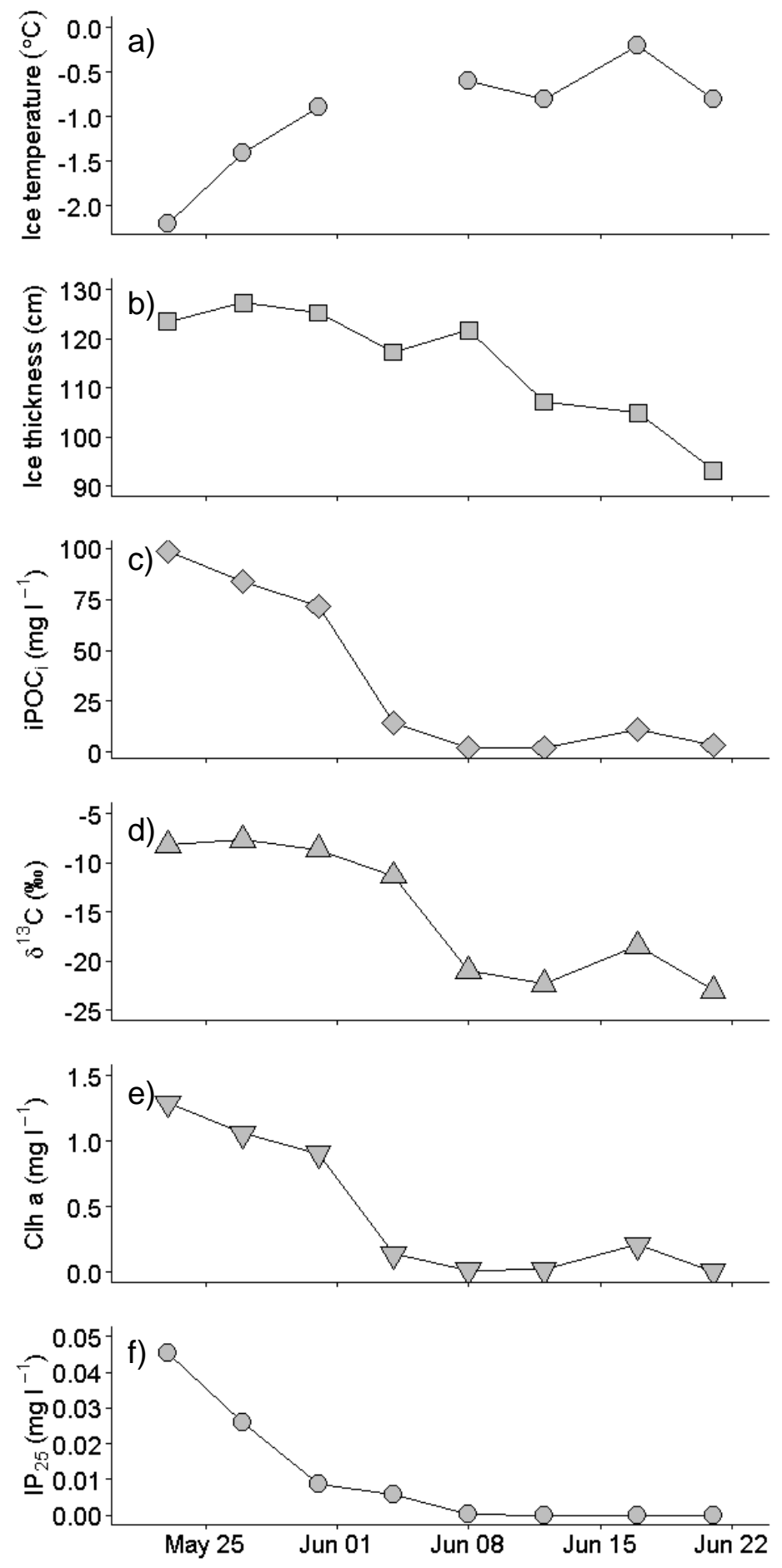

725 Figure 1. 
Disclaimer: This is a pre-publication version. Readers are recommended to consult the full published version for accuracy and citation.

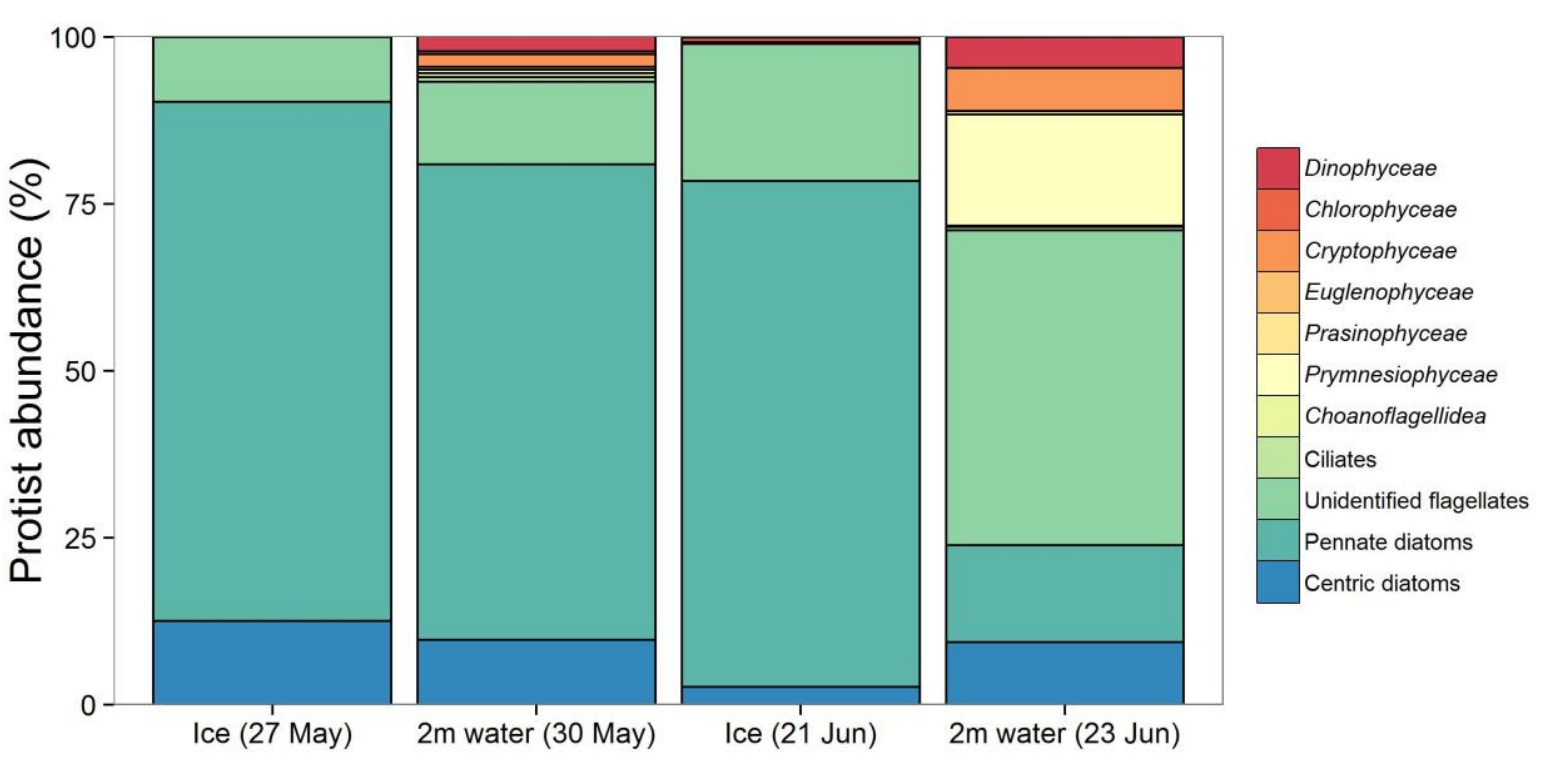

$728 \quad$ Figure 2 
Disclaimer: This is a pre-publication version. Readers are recommended to consult the full published version for accuracy and citation.

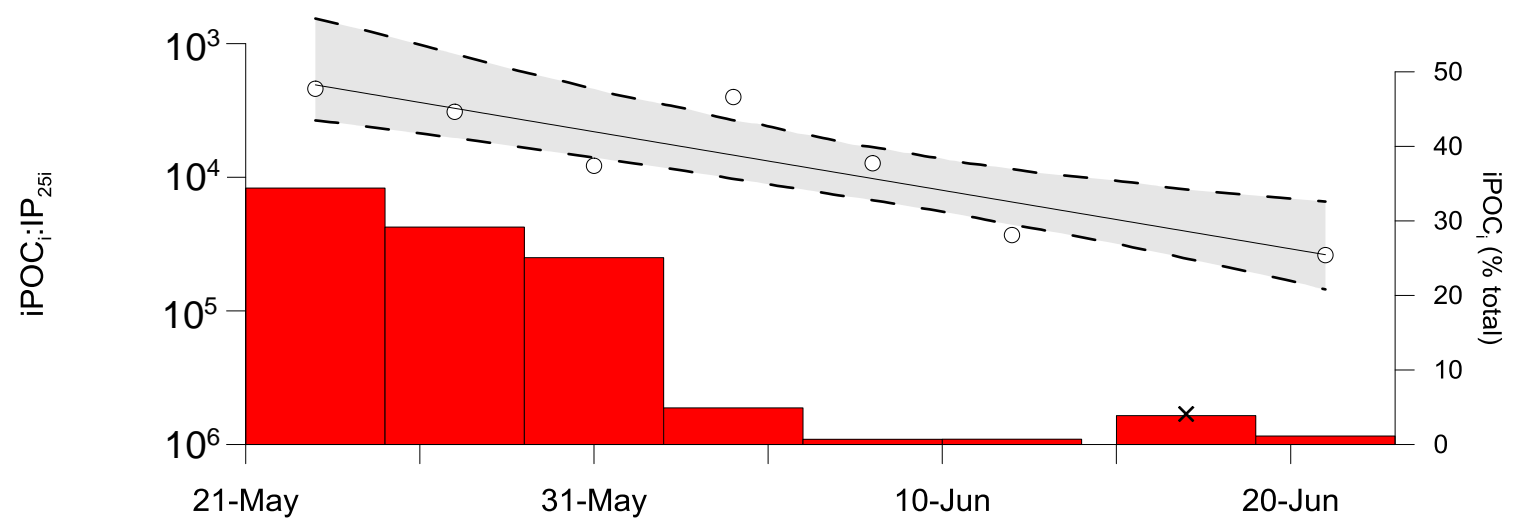

$730 \quad$ Figure 3. 
Disclaimer: This is a pre-publication version. Readers are recommended to consult the full published version for accuracy and citation.

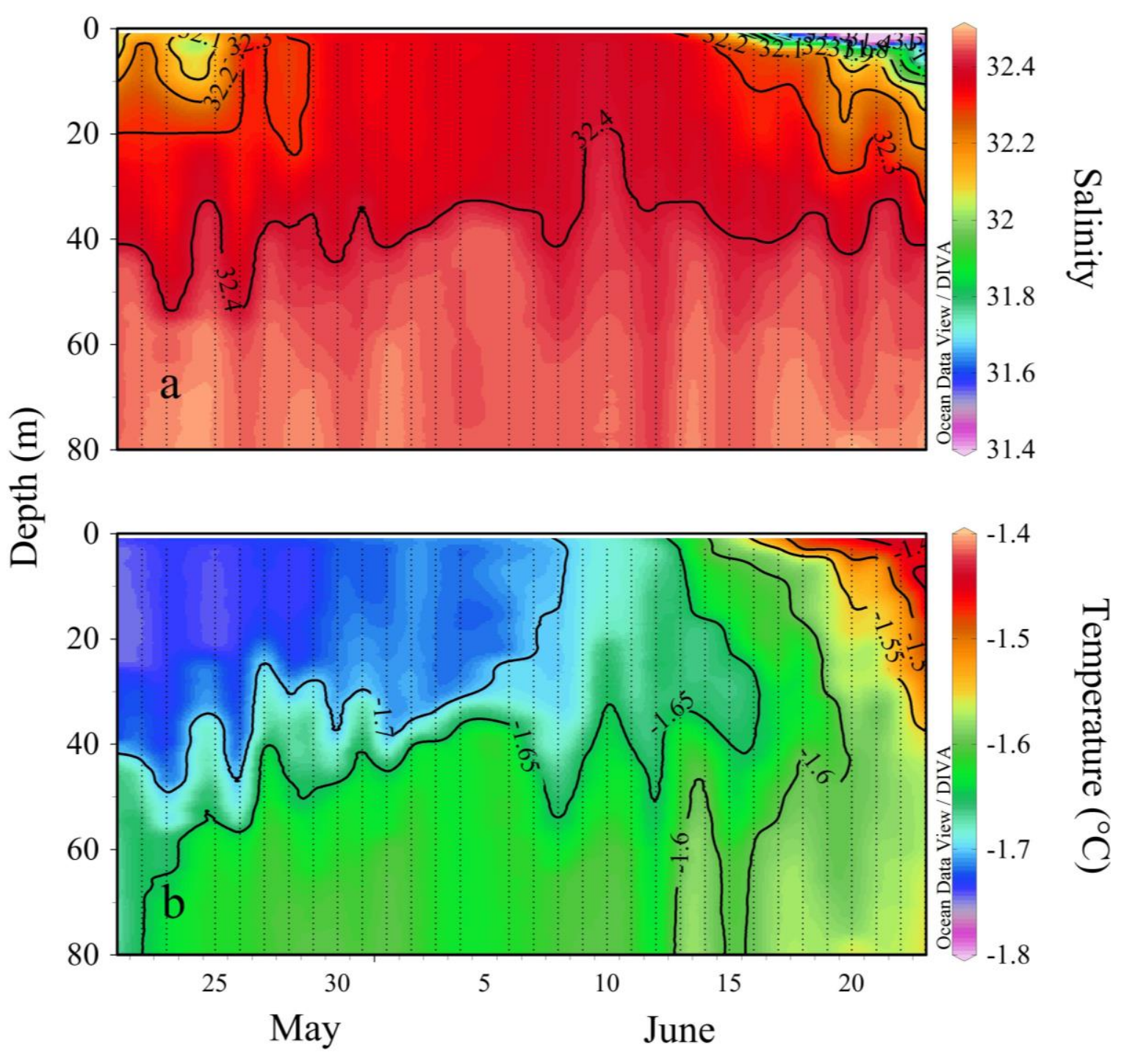

732 Figure 4. 
Disclaimer: This is a pre-publication version. Readers are recommended to consult the full published version for accuracy and citation.
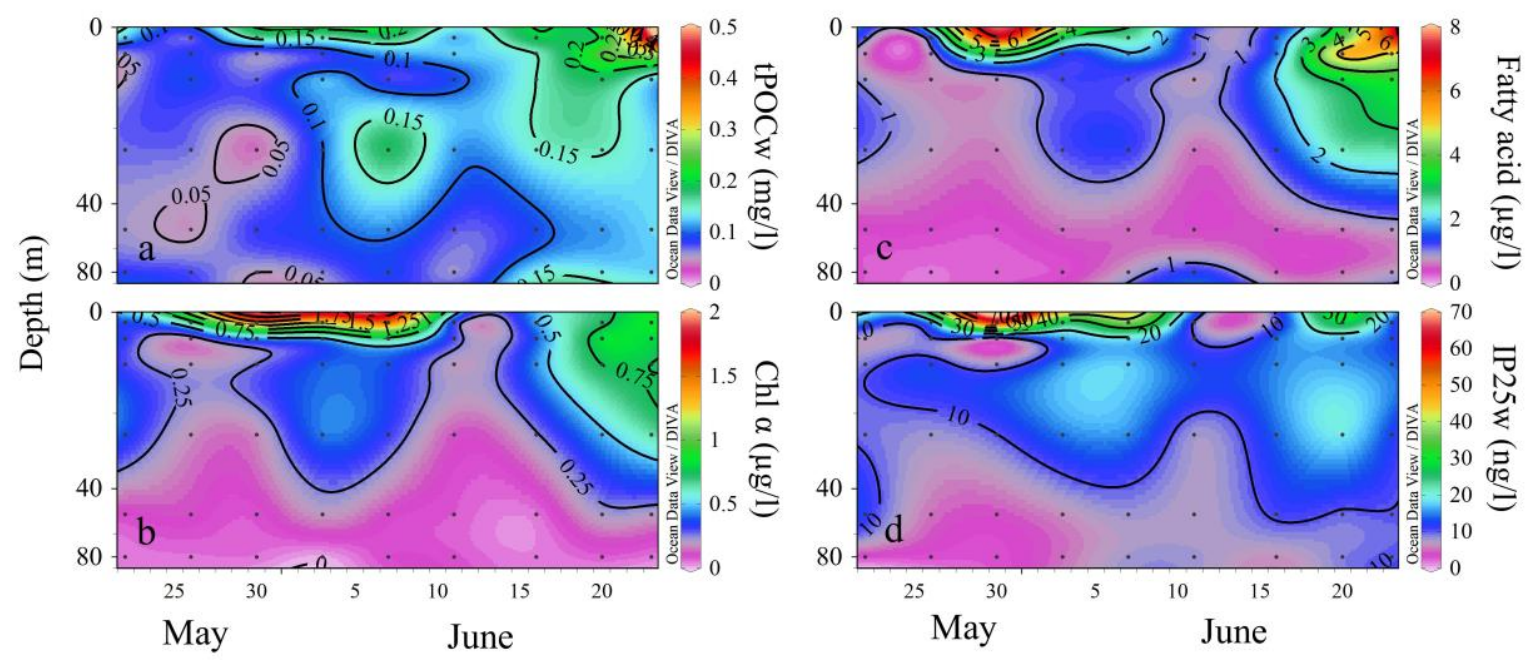

734 Figure 5. 
Disclaimer: This is a pre-publication version. Readers are recommended to consult the full published version for accuracy and citation.

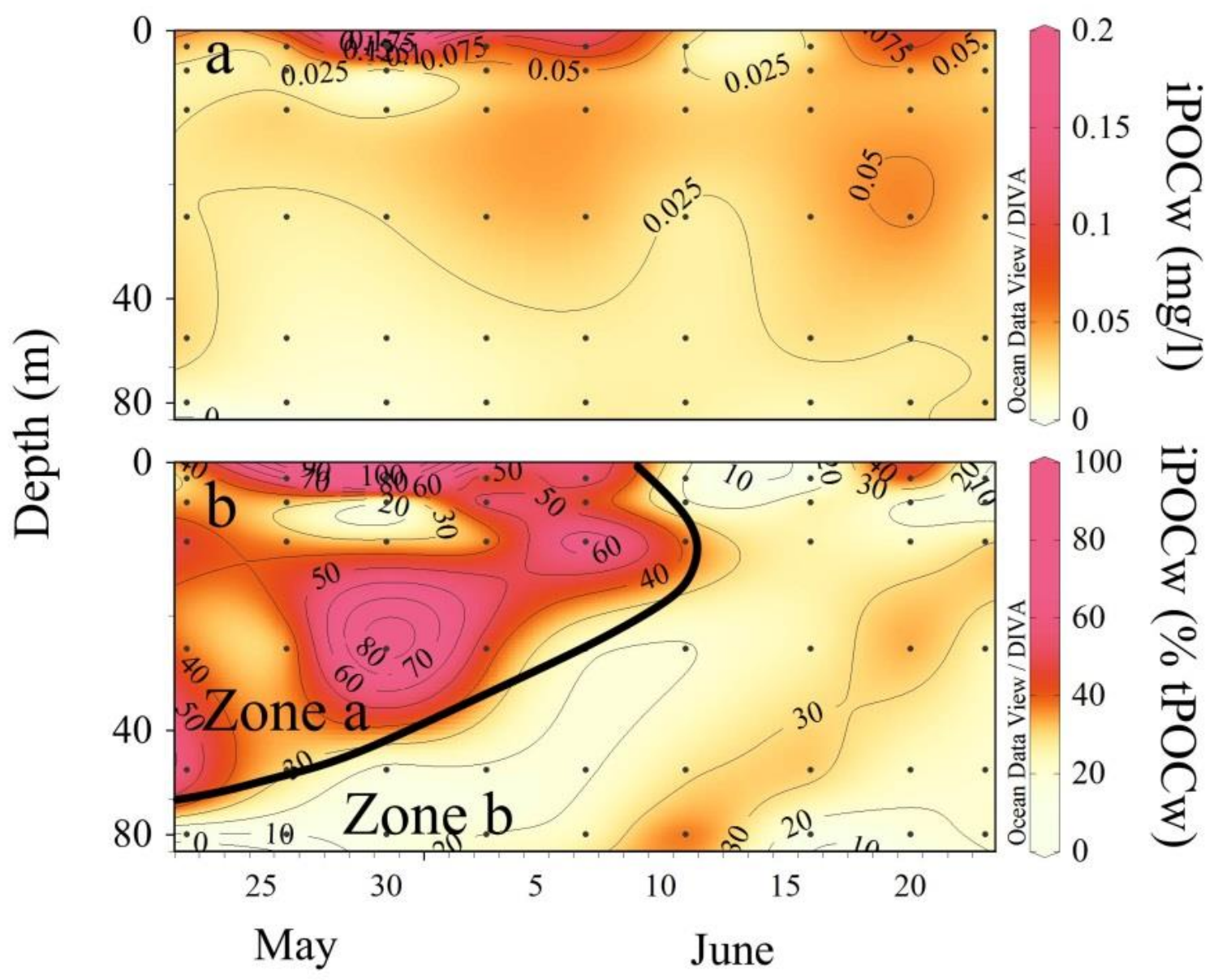

736

737 Figure 6. 